Migration after Empire. Postcolonial masculinities and the transnational dynamics of subalternity

Sofia Aboim (corresponding author)

Instituto de Ciências Sociais, Universidade de Lisboa

Email: sofia.aboim@ics.ulisboa.pt

Pedro Vasconcelos

ISCTE- Instituto Universitário de Lisboa

Email: pedro.vasconcelos@iscte.pt

To cite this paper:

Aboim, Sofia \& Vasconcelos, Pedro. 2020. Migration after Empire. Postcolonial masculinities and the transnational dynamics of subalternity. Postcolonial Studies. DOI:10.1080/13688790.2020.1846848 


\title{
Migration after Empire. Postcolonial masculinities and the transnational dynamics of subalternity
}

\begin{abstract}
Drawing on a qualitative study on migrant men recently arrived in Portugal, this paper examines how the experience of migration leads to the rebuilding of masculinity. The experiences of discrimination and strategies of resistance are linked to the history of Portuguese colonialism and the ways men hailing from contrasting colonial and postcolonial geographies within the Portuguese Empire (Brazil, Mozambique and Cape Verde) discover their subordination in the Portuguese context. We advance two central ideas. Firstly, we engage in an active historicisation of transnationalism and defend the postcolonial character of migrant masculinities. Rather than neutral or a-historical, transnational experiences of migration are better interpreted through the lens of specific histories of colonialism and postcolonialism. Secondly, while recognising the centrality of the hegemonic model of masculinity, we argue that the conceptualisation of masculinity as a complex structure of material and symbolic capitals permits to avoid one-dimensional accounts of subordination and dominance. Furthermore, the notion of capital is helpful for tying together the micro-enactments of masculinity and the macrohistorical dynamics of colonialism and postcolonialism. Expanding the notion of postcolonial masculinities implies working with renewed tools suited for analysing how subordination is perpetuated through colonial devaluation or contested via the mobilization of certain capitals.
\end{abstract}

Key Words: Masculinity, hegemony, subordination, migrant men, postcolonialism, transnationalism 


\section{Introduction}

The formation of transnational regimes of governance primarily ruled by the 'owners of the world below-captains of industry, financial barons, political elites and media tycoons ${ }^{1}$ occupied centre-stage in developments that over time reshaped the model of hegemonic masculinity advanced by Raewyn Connell in the 1970s and 1980s. ${ }^{2}$ The idea of a transnational business masculinity ${ }^{3}$ came later to be equated with hegemonic masculinity in an interpretation that prioritised financial capital in the definition of male power. However, although Connell realised that 'There were sophisticated sociological theories of class, but not of gender', ${ }^{4}$ social class was never the single criterion for explaining the hierarchy of masculinities. ${ }^{5}$ Sexuality, gender identity or racialized discrimination also played a central role. For Connell, hegemonic masculinity is a system of hierarchical plurality that emerges from the intersection between different principles of power and subordination played at local, national, transnational and global levels. ${ }^{6}$

Often, the hierarchy of masculinity contained in the hegemonic model was subject to misinterpretation and reductionism, whether hegemonic masculinity is understood as a specific type of masculinity performed by a group of men or as a free-floating ideal, which hardly captures men's doings of gender. ${ }^{7}$ We believe nonetheless that hegemonic masculinity is a useful theoretical tool. Not only is hegemonic masculinity erected upon a variety of power differentials shaped by complex interconnections but it also captures the trans-scalar dynamics of masculine power working at the global level. However, if the transnational angle came to be one major cornerstone of the theorisation about men and masculinities - as evident in Connell's later formulation of managerial masculinities - the expanding processes of transnationalisation have set difficult challenges to research about men and masculinities. ${ }^{8}$ These challenges must necessarily lead us to reconsider the power relations that uphold the model of hegemonic masculinity. ${ }^{9}$ As Connell wrote 
'Hegemonic masculinity is always constructed in relation to various subordinated masculinities as well as in relation to women. ${ }^{10}$ Consequently, we may assume that classbased transnational business masculinities establish global dominance over localised nonwhite or non-heterosexual masculinities.

In spite of the wealth of contributions on subordinated and marginalised masculinities (henceforth subordinate or subaltern), ${ }^{11}$ there is still a dearth of research about the principles of subordination shaping non-hegemonic positions at the global level. Taking this gap as our starting point, we seek to contribute to expanding the necessary conversation on subordinate masculinities, which remain under-theorised in Connell's model. While class-based dominance of transnational managers has been under heavier theoretical scrutiny, subaltern positions, for the most part, have been empirically conflated with race, ethnicity and men in or from the Global South. ${ }^{12}$ Moreover, race, sexuality and class appear enmeshed under the umbrella designation of subordinate masculinities, a shorthand to name what is opposite to hegemonic principles of whiteness, heterosexuality and breadwinning. ${ }^{13}$ Simultaneously, the concern with migrant, transnational or diasporic masculinities generates new umbrella terms that respond to the need for concepts that enable to account for continuous flow of people and ideas from one corner of the globe to the other, normally from the Global South to the Global North.

In the face of the problem, we seek to further advance the notion of postcolonial masculinity. Although the term is not new, ${ }^{14}$ we contend that postcolonial masculinities deal with the subalternity forged upon racialised relations of power. Adjusting Connell's initial configurations of masculinity, we believe that the subaltern positions of non-white men might be further conceptualised if we bring in the specific hierarchical positions that were historically produced by colonialism. Our view of postcolonial masculinities was triggered by an empirical investigation that focussed on different groups of newly arrived 
immigrant men living in contemporary Portugal. When exploring the ways in which migrant men rebuild their masculinity, we understood that any reflection on migrant, transnational or diasporic masculinities would fall short if oblivious of the history of colonialism or solely oriented towards one-dimensional axes of inequality, be it race or class. From this perspective, our analysis of financially disadvantaged migrant men in Lisbon privileges an intersectional perspective towards the reconstruction of masculinities, which implies renegotiating the valued traits and symbols of masculinity. These strategies are linked to the history of Portuguese colonialism and the ways men hailing from diverse and contrasting colonial and postcolonial histories within the geographies of the Portuguese Empire (Brazil, Mozambique and Cape Verde) rediscover their subordination in the Portuguese context. Such a perspective implies that we bring modernity and postcolonialism into the equation inasmuch as gender and power, while underpinned by various transnationalisations, cannot be viewed as ahistorical. In this sense, Portugal, as a semi-peripheral country to where migration has been mainly weaved by former colonial encounters, offers an excellent setting from which to explore experiences of displacement as a sort of remnant of the lost empire.

In the section that follows, we seek to expand the conceptualisation of postcolonial masculinities as transnational undertakings anchored in the history of colonial and postcolonial oppression. Recognising the hierarchy between masculinities, we argue that subaltern and dominant positions are recreated, in each historical context, by multiple strategies designed to obtain personal value in ways that translate the marketised narratives of migrant men. Following an inductive strategy, we propose the concept of masculine capital as a tool to analyse the dynamics of postcolonial masculinities. Secondly, we situate our microanalysis of migrant men's masculinities in the larger historical dynamics of colonialism and postcolonialism. We suggest that transnational 
approaches must be grounded in the history of colonial empires that developed alongside the expansion of capitalism and modernity. Their complex and plural configurations enabled us to understand the narratives and strategies of migrant men. Thirdly, we describe how the participants in our study dealt with and resisted the multiple oppressions (of race, class, gender or sexuality) they encountered in Portugal.

\section{Postcolonial masculinities}

From the 1980s onwards, the conceptualisation of the model of hegemonic masculinity brought transnational masculinities to the frontline as a means to the formation of a new historical hegemony - that of corporate managers and global finance. ${ }^{15}$ However, even if corporate managers are still playing the main role in the game of male power, there are today other fundamental linkages between transnationalism and masculinities.

Research focusing on migrant men has expanded and provided us with a rich body of empirical information on how subordinate masculinities are compelled to change, at least to a certain degree, when men have to adjust to a different gender order and different norms of masculinity. ${ }^{16}$ However, the inquiry into the adjustment to or the embodiment of western masculinities has left a gap in theorisation. In spite of the wealth of the research undertaken, ${ }^{17}$ there is still an urgent need to expand our conceptualisation of subaltern masculinities. They are, after all, transnational endeavours working at the global level through the intersection of multiple forms of inequality, such as class, race or sexuality. If transnational business masculinities symbolise the triumph of global neoliberal capitalism, transnational processes also forge subaltern masculinities. In this way, alongside global finance, processes of racialisation are increasingly transnational inasmuch as the flow of bodies and racial categories, often dispersed through the scapes 
of imagination (to add an additional dimension to Appadurai's ${ }^{18}$ conceptualisation), moves beyond national borders and even the edges of old empires. Hence, postcolonial masculinities bring in the historicity of power relations between colonisers and colonised in both past and present. Consequently, postcolonial masculinities also permit to illuminate transnational processes of re-encounter between the colonisers and the colonised or subaltern. Without forgetting that there is a particular, but widespread, power relation that stems from old forms of domination, exploitation and enslavement.

Consequently, a reflection on subalternity and hegemony that moves beyond the local and the present, must consider how specific transnationalisation processes moulded masculinity across time and place. Therefore, we need renewed tools for analysing how subordination is perpetuated through the combination of a plural set of intersected discriminations that might be contextually reinterpreted and even reinforced. When migrant men move between different places, men's enactments of masculinity and the value of a given masculinity might change. In this way, men may lose, or even increase, their 'masculine capital', a concept proposed by Anderson to measure the 'masculine level of a man'. ${ }^{19}$ Indeed, a prised masculinity can take multiple forms. From the stereotypical image of white successful corporate managers to black hip-hoppers, from fierce military to famous football players. The array of different symbols associated with a powerful masculinity enables men to rebuild their position, whether of dominance or subalternity, in diverse ways. Often, acts of reconstruction pertain to the level of discourse to the detriment of material privilege. The emasculation of 'materially' powerful men ${ }^{20}$ and the building up of a phallocentric masculinity, ${ }^{21}$ ranging from explicit violence to the explicit investment in forms of 'bodily' ${ }^{22}$ or 'physical'23 capital constitute well-known examples. Sometimes discursive enactments compensate for the lack of other capitals. ${ }^{24}$ Poor migrant men (like those in our research) are not materially powerful, but their global 
subordination does not deter them from aspiring to power and carry through strategies of self-valuation to avoid complete subjection. ${ }^{25}$ Therefore, in our view, men's enactments of masculinity involve both material and discursive elements that might be better conceived as a complex structure of material and symbolic capitals.

The notion of capital is helpful for tying together the micro-enactments of masculinity - as in Anderson' ${ }^{26}$ or Coles ${ }^{27}$ Bourdieu-inspired theorisations of masculinity and capital - and the macro-historical dynamics of colonialism and postcolonialism. Rather than a linear hierarchical system where specific principles of discrimination determine a given subordinate position within the order, by conceptualising masculinity as a structure of competing capitals (not afar from Coles' notion of field of masculinity), we can better understand masculinity as an effective though flexible and multifaceted, practice. From this angle, each capital (whether material or symbolic) can be strategically mobilised and performatively enacted in different spheres and with different meanings. Hence, instead of a hegemony constituted by stable power hierarchies grounded on the cultural rule of a group or class of men, in the Gramscian sense, male power can be reproduced through tension and struggle. ${ }^{28}$ The notion of capital can therefore be useful to grasp multiple and intersected axes of inequality. It might help us avoid the traps of working with an excessively linear and hierarchical positioning of the dominant as opposed to the subordinate, a reasoning that may well occur when we carelessly use the concept of hegemonic masculinity.

In the conceptualisation of capital, the definition proposed by Bourdieu enables us to conceptualise capital not only as something with a material value but also as something (or someone) with a specific symbolic value, thereby forging an economy of symbolic exchange. ${ }^{29}$ Nonetheless, although paramount, Bourdieu's approach is not ample enough, for two reasons. Firstly, it privileges a class-over-race determinism. 
Secondly, the concept of capital is too tied to a strict definition of field, with often one type of capital prevailing in one specific institutional field and being of little value in another field. ${ }^{30}$ Therefore, if we want to conceptualise masculinities as a structure of capitals, appropriated, transformed and performed by subjects, we need to enlarge our notion of capital beyond the limits imposed by fields in Bourdieu's conceptual architecture. ${ }^{31}$

One way of tackling this problem could imply going back to the root, to Marx's conceptualisation of capital and taking his theory of value as the main starting point. ${ }^{32}$ However, in order to avoid the trap of an excessive materialism that obfuscates our view of domination as also symbolic, poststructuralist approaches to power can be quite illuminating. That is perhaps the better way of giving concepts such as sexual or bodily capital theoretical sustainability, while also crystallised forms of socially produced value, which can be fought for and exchanged. In a way, and following Baudrillard's reasoning on the 'object value system', signs and symbols can be exchanged as commodities insofar as meaning (which can equal exchange value in a Marxian sense) is created through difference. ${ }^{33}$ Generated within an economy of meaning whose foundations exceed the determinism of material production, as argued by Baudrillard, the difference must then be placed in the context of colonial history, postcolonial encounters and transnational capitalism.

Against this backdrop, we suggest that the notion of postcolonial masculinities is fitted to signal the continuous subalternisation of those subjected to hegemonic powers from imperial days to nowadays. Analyses of postcolonial masculinities should acknowledge the coloniality of subaltern and hegemonic masculinities and further advance our understanding of transnational dislocation while dependent upon the history of colonial encounters. After all, the hegemony of white-upper-class corporate managers 
is as colonial as the subalternity of non-white-poor migrants. Indeed, while slavery is often considered as pre-capitalist, Hardt and Negri ${ }^{34}$ argue that the largescale colonial slave production system underpinned European capitalism economy. ${ }^{35}$ While representing a form of transnationalisation, postcolonial masculinities emphasise the historical domination of the colonised and suggest that contemporary transnational dynamics are produced by that very same history.

In fact, we follow Connell very closely. As she emphasised in a 1998 interview: $^{36}$ 'Hegemony in gender relations is a process, a historical relationship, and not a fixed pattern (still less a type of personality). The Western impact on the colonial world ruptured gender orders and initiated an endlessly complex struggle for new relationships.'

The history of colonial violence marks both the structural order of gender and society but also the self and their capacity for agency. However, agency can only become centre-stage if we avoid one-dimensional explanations or determinisms and work with a plural and flexible conceptualisation of inequality. Hence, in our analysis of financially underprivileged immigrant men, we mobilise the micro-macro linkages implicated in the reconstruction of masculinities, considering that postcolonial practices are a form of transnationalisation deeply linked to the history of Portuguese colonialism. From such a perspective, postcolonial masculinities - and the resistance of subaltern men through the mobilisation of certain capitals - cannot be fully apprehended without debating the workings of gender and power vis-à-vis the influence of the colonial and post-colonial dynamics of societies. This implies engaging in an active and explicit historicisation of transnationalism, which is never neutral or a-historical. For us, the historicity of the transnational can be better formulated under the broader concept of modernity, especially 
when mobilising the postcolonial critique to Eurocentric views. After all, in a world shaken by massive changes in gender relations, men's lives and masculinities reveal, at the micro-level, the entanglements of modernities. ${ }^{37}$ Although capitalism and modernity are conceptually different and 'the meaning of modernity exceeds the one of capitalism in the sense that it refers to a general societal self-understanding, ${ }^{38}$ the connection between both terms is deep. As Casassas and Wagner argue, while the 'economic problématique' of capitalism is but one aspect of modernity, the imaginary of autonomy that rose in the eighteenth century became the basis of all market-based social relations and ideals of free agents. In this vein, we concur that capitalism, modernity and (as argued in the next section) colonialism are not dissociable. Even if institutional forms of markets, states and systems of gendered domination may vary across time and space, any act of historicisation must, therefore, recognise their common norms and shared pathways.

\section{Historicising transnationalism}

Postcolonial scholars, and most of the critics of Eurocentric and westernised views of modernity, have argued in favour of plurality, either announcing the end of modernity and the consequent shift to a post-modern era or alleging that, rather than expand in a homogeneous flow, modernity has evolved in multiple pathways. The latter implies the redefinition of modernity itself, leaving behind ideal conceptions of a congruent history and process. As Bernard Yack ${ }^{39}$ radically argued, socio-economic and cultural practices do not fit coherently together, and viewing modernity as a coherent whole is a particular type of fetishism. Undoubtedly, postcolonialism continued the best tradition of critical theory and had a crucial role in deconstructing modernisation theories, which, in the 1950s, tried precisely to cope with the fall of colonial empires, establishing patterns for universal development guided by the supremacy of western modernity and a-historical 
views of globalisation as the motor force of the neoliberal agenda in the aftermath of colonial struggles. ${ }^{40}$ For this reason, we believe that any forgetfulness of colonial history when debating transnationalism or globalism is misleading, if not dangerous.

The truth, however, is that the particular history of societies has commonly been read through lenses that betray wider visions of modernity as a whole. Classificatory schemes that make use of sociological embedded dualisms, such as the traditional/modern binary, provide us with an excellent example. The resilience of these dichotomies stemming from Weber's, Durkheim's or Marx's concern with social change in the nineteenth century made it difficult to escape the paradigm of modernisation to which binary categorisations are referenced to. The opposition between male/masculinity and female/femininity is no exception. The lasting opposition between hegemonic white masculinities and racialised subalternity is no exception either. On the other hand, the opposite post-modernist view frequently set off a difficult conciliation between the globalised economic dynamics dominated by successful white men and the local culture associated with race and ethnicity of often agency-deprived social actors.

From this perspective, Eisenstadt's ${ }^{41}$ conception of multiple modernities or Therborn's ${ }^{42}$ idea of entangled modernities may constitute key concepts for rethinking the complex outcomes of trans-scalar gender change. The conceptual pluralisation of modernity can, in addition, offer useful tools for micro-analysing the hybrid outcomes of precolonial, colonial and postcolonial encounters. ${ }^{43}$ Indeed, the centrality of European colonialism in the rise of contemporary modernity points directly to the historical character of globalisation or transnationalism. Furthermore, several modernities may be tied together in postcolonial societies, whether Portugal (the receiver country) or Brazil, Mozambique and Cape Verde. Historically, the features associated with western liberal modernity (e.g. capitalism, nation-state, autonomous individuality) are important, but 
other modernities also took part in postcolonial developments. Human rights may have become the legitimate directive to guide political and institutional action (as Beck proposed) ${ }^{44}$ but custom has not ceased to be a powerful force. Nor has resistance been wiped out of existence. Following Homi Bhabha, ${ }^{45}$ the subaltern condition is not synonymous with an absence of agency. Furthermore, the creativity of agency, stressed by postcolonial scholars, is of great importance to the necessary gendering of a plural modernities perspective. In other words, our purpose is to rethink how the historical character of globalisation (from colonial empires to postcolonial settings) affects transnational experiences of gender power and male identity. It is, therefore, this open character of modernity ${ }^{46}$ that allows for the plurality of identities, and masculinities, in today's world.

Our effort of historicising transnationalism (where postcolonial masculinities come alive) through the perspective of plural modernities obliges us to critically address the concept of globalisation while reinforcing its contextuality. Globalisation cannot be viewed simply as the spread of western modernity or as an undisputable eroding force against the nation-state that favours the new empire of neoliberal capitalist forces. Globalisation is not dead either; nor are political nationalisms or transnational struggles capable of dethroning international finance. It matters still that we consider global processes as uneven and contradictory systems of fluxes between centres and peripheries. Fluxes often associated with the historically-bounded dichotomy between the west and the rest. For better and for worse, contemporary globalisation may be broadly seen as the heuristic device connecting the global, the national, the local and supporting the transnational flows between old colonisers and postcolonial societies.

From this angle, we must formulate an inquiry into the ways through which globalisation enabled the production of inequalities that fed the power of the west over 
the other, of postcolonial elites over the people, of some men over others and over women. Remembering Frantz Fanon's Black Skin, White Masks, ${ }^{47}$ contemporary processes of hegemony and subalternisation mimic still the transformation of subjection (colonial racism) into subjectivity. However, it is also true that alongside violence and domination, globalisation brought also into play a history of resistance, change and creativity, a history of civilisational encounters but also of inner transformation and permanent recreation. Consequently, following the contributions of hybridisation globalists, ${ }^{48}$ we need to understand postcolonial agency. Resistance and creativity are, after all, largely produced by intricate processes of hybridism, which, according to Bhabha, create a third space that enables other positions (neither subaltern nor dominant) to emerge. As a result, the linkages between the capacity for agency and notions such as multiple or entangled modernities alert us that neither the global is completely erosive nor local masculinities exist outside of transnational flows and encounters. In those encounters men mobilize their masculine capitals, which when reinterpreted in a given economy of meaning (as in Baudrillard), gain significance as tools for resisting domination and achieving a sense of self-worth. Although the species of material and symbolic capitals that are valued might be context-specific, the analysis of particular struggles for gaining certain masculine capitals offered us a fruitful lens for comparing stories of migration of men coming from Brazil, Cape Verde and Mozambique.

\section{Migrant men in the postcolonial society}

\section{Overview of the study}

The research on the doings of gender among recently arrived immigrant men living in the metropolitan area of Lisbon sought to attain a wide diversity of colonial and postcolonial histories vis-à-vis the old colonial centre. 
Although the percentage of migrants in Portugal is fairly low (5.5 per cent in 2018, according to the Portuguese National Institute of Statistics), nearly 41 per cent came from former Portuguese colonies in Africa and from Brazil. Migrants are particularly concentrated in the metropolitan area of Lisbon, where half of the foreign population is settled. These numbers rise even more dramatically in the case of migrants originating in the former African colonies and Brazil: in 2018, 78 per cent lived in Lisbon. However, while Brazilians (20 participants) are, today, the larger migrant group in Portuguese society, representing 21.9 per cent of all the migrant population in 2018 , immigration from the former African colonies decreased slightly over the past decade. Nonetheless, in 2018 African migrants represented 18.8 per cent of all registered foreigners. The majority came from Cape Verde (7.2 per cent) and only a small minority migrated from Mozambique (only 1 per cent). The choice of Cape Verdeans (10 participants) and Mozambicans (15 participants) represents therefore not a statistically-oriented option, but rather a selection underpinned by the history of Portuguese colonialism in Africa. ${ }^{49}$ Although the vast majority of migrants face discrimination and hardship (with at least half of migrants living below the poverty line $)^{50}$, the way Cape Verdeans, Mozambicans and Brazilians struggle to make ends meet and reconstruct themselves as men in postcolonial Portugal is not necessarily identical. The marks of the colonial past are enduring.

Both Mozambique and Cape Verde only attained independence in 1975, after a thirteen-year national liberation war (1961-1974) against the Right-wing authoritarian and conservative Portuguese regime of the Estado Novo (1926-1974) ${ }^{51}$ and only after the 1974 Left-wing revolution in Portugal that established parliamentary democracy. This would lead to the Mozambican Civil War, between 1977 and 1992 (in the context of the Cold War), that, amongst other factors, highly crippled Mozambican development efforts. 
In contrast, Cape Verde was not affected by military action during the Portuguese Colonial War. More importantly, within the late Portuguese colonialism in Africa, Cape Verdeans and Mozambicans represent a contrasting colonial background and exemplify, at each pole of the spectrum, opposite colonisation strategies.

Portuguese colonialism in Mozambique in the $20^{\text {th }}$ century was a strongly racial one: not only the legal difference between 'Blacks' and 'Whites' was paramount, but also indigenous populations were constrained to harsh forms of forced labour. From 1961 onwards, after the beginning of the Colonial War, European settlement highly increased. The preponderant colonial system was basically akin to apartheid, enhanced (when compared to Angola, for instance) by the proximity of South Africa and the importance of British economic interests in Mozambique.

Cape Verdean society, however, is the result of a very different colonial history when compared with other Portuguese colonies in Africa (with the relative exception of São Tomé and Príncipe). The islands of Cape Verde were uninhabited before Portuguese discovery in 1460 . The colonial strategy followed by the Portuguese state produced a mixed society, resulting from the mingling of Portuguese settlers and dislocated Black Africans, even if power always remained in the hands of a white (essentially male) elite sent forward from Lisbon to administer and control the territory. This social and cultural hybridity - quite visible in Cape Verdean Creole language - makes Cape Verde somewhat closer to the creole world of the Antilles than to mainland Africa. This creolisation process also influenced racial identities and categories. Overall, Cape Verdeans do not tend to perceive themselves as 'Black' but as mixed (Mestiços). From the onset of independence, Cape Verdeans also started migrating to Portugal to escape underdevelopment and lack of opportunities. Within our study, participants from both groups have similarities in terms of age and socio-economic background. The majority of 
participants are in their twenties and thirties, come from lower classes, have lowerincomes, hold a lower education level and are more likely to work in odd jobs or be unemployed. Nonetheless, Mozambicans' and Cape Verdeans' experiences of migration and integration in Portugal are considerably different. These differences are into a great extent the product of experiences moulded by the legacies of Portuguese colonialism and the subsequent construction of very diverse postcolonial societies.

The third exemplary case, Brazil, is very different. On the one hand, Brazil's independence was attained quite early on, in 1822 in the context of the South American liberations of the early $1800 \mathrm{~s} .{ }^{52}$ From the onset of independence, as before, Brazil became a recipient society of Portuguese migrants (particularly after the abolition of slavery in 1888 , in a political guided effort to increase the 'whiteness' of Brazil's racial makeup). This migratory trend remained regular until the 1950s. As a result, Portuguese migrants (most of whom of illiterate peasant origin), and by contagion Portugal, were devalued, even if Brazilian ethnogenesis and culture are highly indebted to Portuguese contributions. Nonetheless, Brazilian relations to the former colonial power remain ambiguous. Although Brazil can be characterised as a European settler society, the integration of demographically significant Black African and Native American indigenous populations remains filled with contradiction. Even if official $20^{\text {th }}$-century rhetoric hailed it as a racial democracy, Brazilian society is stage to complex and hierarchical categories of race and colour whose apex remains whiteness. On the other hand, Portugal became increasingly seen in the last decades as a rich western European country, and whose culture is often perceived by Brazilian as similar to their own - not only linguistically, but also regarding sociability.

The receiver society for these different migrants, Portugal, even if a colonial power since the fifteenth century, could be characterised as a backwards European society 
until the changes brought forth by the revolution in 1974. During most of the twentieth century, it had been dominated by an authoritarian, conservative and colonialist dictatorship. Although Portuguese colonial practices were highly racist, official discourse denied it, emphasising instead the ideology of 'luso-tropicalism' as put forward by Brazilian anthropologist Gilberto Freyre in his landmark book, Casa Grande e Senzala, dated from $1933 .{ }^{53}$ Freyre's luso-tropicalism, while strategically appropriated by the Portuguese dictatorship, praised the supposed Portuguese lack of racial discrimination and soft colonialism in a tentative and progressive ideological differentiation from stereotypical British colonialism. ${ }^{54}$

Notwithstanding, semi-peripheral Portuguese culture and society is pervaded by racial thinking and categorisations, hailing not only from colonial history but also from the long centuries of the Inquisition's persecution, expulsion and demise of Jewish and Moorish (Mouriscos) populations, ${ }^{55}$ and can be presently characterised as one of systematic racism. ${ }^{56}$ Even if official discourse and legal regulations are straightforwardly anti-racist, racism remains a ubiquitous force in Portuguese society.

\section{Participants and the field}

Aiming to understand the experiences and discourses of migrant men, we interviewed 45 recently arrived immigrants from Brazil, Cape Verde and Mozambique. All had arrived in Lisbon between 2009 and 2012. Interviewed in 2012 and 2014, all participants were recently arrived migrants still struggling to integrate and value themselves. Overall, since the 1970s the socio-economic profile of African migrants has remained largely underprivileged. In the case of Brazilians, the profile of migrants is more varied, with recent waves of upper class and mostly white Brazilians coming to Portugal in recent years. ${ }^{57}$ Aged between 23 and 35, most men in our study were from unprivileged 
backgrounds and migrated out of financial necessity. In their homelands, the majority faced situations of prolonged unemployment or very low pay.

The recruitment of participants involved multiple strategies and the combination of in-depth semi-structured interviews with ethnographic fieldwork. Visits to poor migrant neighbourhoods in the Lisbon area and to the homes, leisure sites and workplaces of participants were key to ensure informed participation in the research. In fact, the contacts made through this strategy enabled us to maintain informal conversations that were vital for understanding the point of view of participants. Seeking to reconstruct the migration experience, the interviews were conducted in various locations always chosen by the participants and lasted between two and six hours following the protocols associated with a semi-structured qualitative approach. In the interviews, participants were asked to reflect upon their migration journey and the experiences of discrimination lived in the host society. Finally, they were invited to also reflect on how these experiences had affected them as individuals in general and as men in particular.

Two narrative streams were central.

Firstly, even if not directly inquired about racial categorisations, the selfperceptions of the racialised body displayed by the different groups of migrant men gained immense relevance. Of the 20 Brazilian men, 15 identified as non-white. While only two categorised themselves as black, the majority used categories of racial hybridity such as 'moreno', 'pardo' and mixed. The majority of Cape Verdeans also used categories other than black (negro, preto), such as simply African and, for the most part, 'mulato', with some immediately emphasising that being considered a 'mulato, crioulo, mestiço' or just a little dark-skinned depends on the context. For Mozambicans, the selfidentification with blackness is quite homogeneous, even if some men dislike the term 'race' and prefer to invoke nationality (Mozambican) and often the categories of ethnicity, 
such as being MaChangana (from the south of Mozambique) or Macua (from the north part of the country).

Secondly, bearing in mind the multiple experiences of dislocation, we analysed the different strategies of self-empowerment when dealing with otherness. Two theoretical premises were key to grasp the narratives of migrant men.

On the one hand, we worked with the postulate that rather than fixed positions determined by the possession or the lack of one specific resource or privilege, masculinity can, in fact, be conceived as a complex, though flexible, structure of competing capitals. We have argued that any analysis of transnational migration should consider multiple axes of discrimination in a postcolonial setting and that looking for the different capitals of masculinity would enable us to pursue that strategy. As such, alongside financial capitals (often associated with a class-based hegemonic position), we considered other material and symbolic capitals capable of being mobilised and performatively enacted in different spheres and with different meanings. We realised, inductively, that bodily and sexual capitals were particularly important, as demonstrated below. In fact, following Bourdieu, ${ }^{58}$ sexual capital, ${ }^{59}$ bodily capital ${ }^{60}$ or physical capital ${ }^{61}$ can be understood as akin to other forms of capital (symbolic, cultural, social capital). Our use of the concept of capital resulted from a bottom-up approach, which prioritised the empirical data, which were coded using both inductive and deductive processes. After all, by awarding a certain value to a certain good (whether material or symbolic), men's narratives emulated, to a degree, the symbolic codes of the capitalist dynamics of economic exchange. Even race and ethnicity gained the contours of a capital ${ }^{62}$ whose value could be negotiated and contested. However, on the other hand, while personal strategies to be/become/have the absent capitals of manhood are paramount, individual agency cannot be read outside the history of any category of dominance or subalternity. 


\section{Displacement and the dialectics of mockery}

Our main findings reveal that these three groups of migrant men have different forms of dealing with displacement, though a number of commonalities were identified. The vast majority of participants felt discriminated and show a clear awareness of the processes of subalternisation operating in contemporary Portugal. The narration of episodes of discrimination and feelings of marginalisation are normally the product of racism and xenophobia. Even if racial discrimination only rarely translates into explicit violence (whether physical or verbal aggressions are at stake), it is still ever-present with expressions more or less subtle in accordance with the overall capitals men possess. The lower the education and the less socially valued the occupation, the more men embody, as a lived experience, the feeling of being discriminated.

For that reason, migrant men grappling with subordination engage in what we can define as the dialectics of otherness, or, in perhaps better words, a dialectic of mockery. They are the Other but at the same time that fetichised otherness ${ }^{63}$ becomes a complex process in which migrant men also transform Portuguese and European men (as well as women) into Others. Nourished by constant acts of mutual misrecognition, otherness is then sedimented as a form of subjectivity in its own right. The sense of otherness urges the subordinate to pursue a number of strategies for disempowering the dominant. Even if migrant men mimic European ways (Portuguese but mainly the westernised imageries of masculinity) they all feel the need to empower themselves by recreating difference, most often through mockery. As Homi Bhabha suggested, 'it is from this area between mimicry and mockery ${ }^{64}$ that resistance emerges and becomes potentially subversive. Mockery works, however, in an economy of exchange, where the capitals of masculinity are reinterpreted and measured against each other, whether in the search of self-worth or 
pursuing symbolic devaluation of the dominant other in the recipient society. As suggested earlier, men mobilize ideals of masculine worth (or masculine capital) and exchange signs and symbols as commodities with value in a given context.

However, although men share common feelings of discrimination, the strategies for dealing with racialised subordination are different. They are underpinned by the history of colonial inheritances and the ambivalent views of Portugal as a European nation that was the old coloniser. In other words, the forms of dealing, through mockery, with the supremacy of whiteness are different for historical reasons. Hence, as we have argued, umbrella labels such as transnational or migrant masculinities fail to signal the postcolonial mould of globalisation or the plurality harboured under the subaltern label. Evidently, we are not trying to formulate a typology of modes of subordination along lines of national origin that might be considered as any kind of universal statement. Rather, we are interpreting the available narratives, to empirically emphasise the theoretical importance of considering colonial and postcolonial history as an analytical lens through which dislocations and all processes of transnationalisation should be considered. From this angle, both discrimination and resistance to subalternisation performed by migrant men stem from particular histories of subordination. Histories that necessarily underpin the dialectics of mockery through which some traits are prised as capitals of masculinity while others are diminished. For this reason, we will firstly describe migrant men's experiences of racialized discrimination and, secondly, how they resist subalternisation by enhancing certain African and Brazilian traits against the flaws of Portuguese and European white masculinities.

\section{Experiences of discrimination}


Indeed, Brazilian migrant men soon discover that they are the subaltern Other. As one man stated (Lucas, 33, unemployed): 'In Brazil I was a normal person, here [Portugal] I discovered I was a stranger... You are seen as a subcategory, like a pariah or something.' Still another one added (Nicolas, 30, construction worker) 'That [being a foreigner] destroys the worth you think you have as a man.' The vehement narratives of Brazilian men, not at all wary of expressing their discontents with discrimination and subalternisation, are - alongside material exploitation - the product of the mismatch between their expectations before migrating and the discovery, at least for many of the interviewees, that they are 'less white', or not white at all, in Portugal than they were in Brazil. For that reason, Brazilian men either strive to hide their 'racial' features (when there is ambiguity according to Portuguese perceptions of race and they are not in obvious conformity with the appearance of a white man) or build up a narrative of praise of their mixed origin, giving extra value to specific Brazilian categorisations of non-white bodies.

Brazilian categories are complex and multiple. The official state-endorsed classification $^{65}$ divides the population into five categories: branco (white), preto (black), amarelo (yellow), indígena (indigenous) and pardo (brown). Notwithstanding the influence of US racial classifications, current official categories of race survived North American cultural imperialism (which enforces a bipolar, one-drop rule, taxonomy) and, more importantly, replicate still the racial lexicons inherited from the colonial period. ${ }^{66}$ At the time, in the first two decades of the eighteenth century, the racial nomenclature reached to about 150 different categories. ${ }^{67}$ In the final phase of Portuguese colonisation of Africa, this complicated taxonomy had become simpler, but never bipolar. The ideology of luso-tropicalism led, in this stage, to the appropriation of a certain racial lexicon by the Portuguese fascist regime that intended to create strategic demarcations from the hegemonic anglophone categories of race. In this way, still today, terms such as 
'people of colour' can be interpreted as diminishing and racist in Portuguese-speaking contexts. Even in Brazil, anti-racist movements abolished this expression since the 1950s inasmuch as people of colour (which in Portuguese is more akin to the English word coloured) hides the colour of whites. ${ }^{68}$ As these were the words of racism, their use became a reminder of colonial racial oppression so much so that racial classifications survive in cultural expressions and institutional practices. Officially, in Portugal, racial categories were abolished from state statistics since the democratic revolution. Yet, the lexicon of anti-racism is far from universal. Rather, racist words are the product of history and cannot be abolished by the force of law.

The response of many Brazilian men, when confronted with Portuguese unofficial racial classifications and the privilege of whiteness, is exemplary in the narrative of Diogo (28, sales clerk), who stated angrily:

'I sometimes get quite nervous when people here call me mulato. I'm not used to that. In Brazil I'm moreno. A mulato is someone darker than me, it's almost a black. When Portuguese call me mulato I get offended, what I am is moreno! I'm no black!'

Again struggling with the still predominant Portuguese categorisations of race, which reflect those applied to the indigenous populations of the former African colonies still surviving in the collective imaginary of the recent past, Josias (31, cook helper), said: 'Of course sometimes you are going to be discriminated because of it, even if you're not black black... when you're in a country where almost everyone has white skin, even if you try to disguise it, they'll discriminate you because you are darker. And I think of myself as moreno, but apparently I must be black, even if I'm not really black black...' 
One other example of the mismatch between expectations of inclusion and racialised discrimination is exemplary among Cape Verdeans. Cape Verdean men, tend also to demonstrate confusing feelings when ambiguously discovering their own blackness in the Portuguese context. The myth of creolisation that survives still in postcolonial Cape Verde obfuscates the racial violence of the colonial past. ${ }^{69}$ Cultural hybridity between Europe and Africa has been emphasised instead. Therefore, some of our participants voice their difficulty with the racialised distance between the two continents. As Danilo (29, student) stated:

'I discovered that the colour of the skin is a big marker, which in the end leads to discrimination. But I... I don't have a race! Or then, I'm in the middle, I am sort of mestiço.'

However, other Cape Verdean participants are far more critical and opt to make their African origin proudly visible. As Leandro (25, precarious restaurant worker) alerted, 'as long as there is racism, all things are confused because it is a racial issue, and that is why being black, being African, is a taboo'.

Mozambicans, who were already aware of their blackness, feel, in spite of this, the reiteration of blackness beyond their expectations. As Emídio (36, construction worker) stated: 'Race... I don't like it.... I'm black, but this is not important. Or it shouldn't be!' On the other hand, a number of Mozambican men reinforce their feelings of belonging by restating their pride in being black, as in the case of Bento (45, cook): 'It is a blessing [being black]... Hell! I didn't want to be white! Now, the white was not enslaved..."

In a way, the old fallacy of luso-tropicalism ${ }^{70}$ whereby the Portuguese would be softer, less racist and more open to stereotypical tropicalist bodily performativities is substituted by the reality of the facts. Then, as Portuguese become colder and whiter, 
migrant men, discovering a stronger otherness than ever imagined, end up by falling in this dialectics of otherness and resort to difference - mainly recreated through sexuality and bodily empowerment - to regain some power. Even if there are plural forms of reconstructing masculinity and many-sided othernesses, subordination has to be dealt with by historically embodied forms of resistance, from rage to indifference. In either case, a feeling of superiority recreated on the basis of one's origins and a certain masculine way of being emerges as a strategic capital of masculinity, and changes men's views of themselves and others. Our findings are in tune with Stuart Hall's ${ }^{71}$ observations on identity and diaspora:

'Cultural identity (...) is a matter of "becoming" as well as of "being". It belongs to the future as much as to the past. It is not something which already exists, transcending place, time, history and culture. Cultural identities come from somewhere, have histories. But, like everything which is historical, they undergo constant transformation.'

\section{Strategies of resistance}

Migrant men may experience subalternisation, but their reconstruction of a postcolonial masculinity implies resistance afar from any stereotype of impassiveness. Among our participants, strategies of resistance to discrimination were common and strongly voiced. Against hegemonic norms of whiteness, Portuguese and European men were often ridiculed inasmuch as they were accused of lacking central capitals of masculinity, from powerful bodies or sexual achievements to the sense of duty and authority of a family man. Bodies and souls would be feeble, almost deprived of the qualities of true manhood that neither Portuguese nor European men, in general, would possess in the right amount. 
Resistance might then invert old stereotypes of the colonised "porno-tropics for the European imagination, ${ }^{72}$ though awarding sexuality the same centrality. Within the ideological economy of colonial empires, sex was considered the Other of civilisation, a dangerous 'threat to social order, modernity and the nation, a threat to progress' ${ }^{73}$ Sexual power is transformed into a valued capital, while the weakness of the dominant is highlighted. Indeed, the weakness of the body and a poor sexual performance emerged as a weapon of devaluation. Portuguese men were generally seen as emasculated and their constant feminisation (as weak and dominated by undesirable women) clearly demonstrates the extent to which femininity is still used as a symbolic weapon of devaluation. ${ }^{74}$ In addition, it also demonstrates how traits of colonial subalternisation, namely the view of Brazilians and Africans as excessively sensuous and sexually driven, are embodied as powerful and are turned against the figure of oppression. For Mozambicans, Portuguese men are 'men in a bottle' (not free to be 'proper' men, subordinated to women and unable to fulfil the breadwinner role). For Cape Verdeans they are weak, soft and sissy ('maricas'). For Brazilians they are sexually powerless and unfit to conquer women. However, if the strategic discursive emphasis on body and sexual capitals is common to the three groups of migrant men, once again enacting postcolonial masculinity brings a certain historically grounded cultural becoming to surface.

For Brazilian men, Portuguese men are overall sexually weak. ${ }^{75}$ Vanderley (35, sales clerk) emphasised: 'They are slack. I'm more of a man then they are!' In a similar tone, Dilmar (29, bartender) mocked Portuguese men's sexuality. Adamantly, Dilmar noticed: 'From what I know their [Portuguese men] sexual performance is worth shit... They have small dicks! And no fire in them.' He added, triumphantly, that 'We [Brazilians] get laid much more than them!' The suspicion placed upon the worth of 
Portuguese men is more than just sexual. It extends to seduction abilities and romantic qualities. As Ariston (29 years old, employed as cook helper) stated:

'We are much more tender and romantic, we know how to be seductive, we have this way...Portuguese are lame and sissy... They do not value a good woman and when they see one, they run.'

A body, a certain mode of performing, a penis, are then transformed into more than mere flesh. Closely following Baudrillard's theorisation, ${ }^{76}$ we might say that they become symbols (insofar as they are assigned a value in relation to a specific subject) and signs (insofar as they gain a value in a system of interconnected and exchangeable objects). In sum, they become commodities in an economy of symbolic exchange and make of masculinity a field of struggles for reinterpretation and possession of certain capitals.

Similar strategies of devaluation are common to all our participants. Nonetheless, Brazilian migrants are not only more emphatic but also more concerned with Portuguese women, whose attributes mirror in reverse the feminine qualities attributed to men. They are often presented as masculine, unpleasant, ugly and without sexual appeal. As Ariston explained: 'They [Portuguese women] do not really feel as women... they are more interested in disputing the space of men! They are very rough...' Concomitant with a depreciative feminisation of Portuguese men, the masculinisation of women enables Brazilian men to praise their own masculine worth as well as the superiority of Brazilian women. In comparison to Portuguese women, Brazilian women are sassier, sensuous, tender, loving, attractive, beautiful, to translate the more common adjectives. Their physical attributes are also incomparable. As Jonas (31 years old, precarious construction worker) said: 'Ah! The curves of the Brazilian woman! Now... Portuguese women... or 
Spanish, or Dutch! Forget it!' Several interviews praise Brazilian women's feminine vanity. Dimas (27, sales clerk) goes to the point of detailing:

'The way they [Brazilian women] dress! They know how to dress. They wear high heels, they use tight pants, miniskirts... Now, Portuguese women... they dress badly, they aren't feminine at all! They are envious of Brazilian! That is why they call them whores. It's just envy!'

In the case of Cape Verdeans or Mozambicans, bodily and sexual capitals are enhanced in a similar way. However, physical attributes do not seem as important as moral qualities, such as the strength of character, sense of duty and responsibility. Portuguese men's inability for sexual or romantic prowess derives from their respective subordination to women. As Miguel (Cape Verdean, 32, unemployed) said 'Portuguese men bow their heads to their women! It's the women who have the final saying!'

For Mozambicans, the inability to fulfil the breadwinner role appears more important. Voicing a common opinion, Orlando (33, university student) considers that Portuguese men fail to provide for their families and to protect women. As Orlando contends:

I was raised to have responsibility, to take care of my family. We respect that and it is very important to be a husband and father who supports the family. It's a sense of responsibility that we have, and here [Portugal] I don't see it. Portuguese men don't care as much. They don't care if the woman does the work and earns the money for them. That's not real responsibility... Men here are spoiled, like my colleagues. They let their girlfriends pay for dinner, and that's not right. I can't understand that... 
Breadwinning appeared as a central feature of responsible masculinity, a notion of great importance for Mozambicans. The recreation of self-worth and the construction of a valued masculinity vis-à-vis the Other mobilises traditional norms stemming from the colonial past, now reversed and targeted against the old coloniser. Indeed, building on precolonial custom and the patrilineal family system that upheld men's power as absolute rulers of their households, Portuguese colonial policies were also keen in disseminating ideals of a male breadwinner model, stressing female subordination. Nonetheless, deprived of any power or worth by the colonial forces, Mozambican men were instigated, or even constrained, to enter the wage-earning system or just forced labour. An ideological view that was also supported by Christianisation processes and the fallacious archetype of the 'assimilado' ${ }^{77}$ which to a certain degree survived as a legitimate model long after being abolished in $1961{ }^{78}$ The colonial ideological imposition conspired to construct men as breadwinners or providers even if, in practice, reserving this right to only very few individuals. Nonetheless, building on precolonial custom and the resistance against the colonial limitations to breadwinning, this ideal that still moulds the aspirations of many Mozambican men.

\section{Conclusion}

Our empirical work led us to further advance three central ideas: the historical formation of transnational flows in the global arena, the postcolonial character of migrant masculinities, and the conceptualisation of masculinity as a complex structure of competing material and symbolic capitals as a way of avoiding either one-dimensional explanations or the reification of subordination and dominance within the hegemonic model of masculinity. We have seen that migrant men from different corners of the colonial world interpret and resist discrimination in different ways. Despite the 
commonalities, not just amongst themselves but also in relation to working class forms of resistance, specific categories of subalternisation and empowerment are forged upon nomenclatures of past colonial oppression. However, despite all the diversity we encountered and sought to interpret, one element of the hegemonic order occupies centre stage. Alongside inherited categories, the postcolonial present does not escape the imposition of the capitalist neoliberal order. Agreeing with Hardt and Negri, ${ }^{79}$ 'globalisation is not a simple process of homogenisation; it implies, in equal measure, processes of homogenisation and heterogenisation.' One such homogenising dynamics belongs to the expansion of a commodified language of capitals, even when combined to specific interpretations and resistances. We then conclude by highlighting the power of one particular global hegemony that can only be perceived, in our view, through the tools of socio-historical interpretation.

From this angle, one striking fact is that by referring to the commodification of masculinity, we are reproducing, via an inductive strategy, the ways in which men organise their discourses and practices, always awarding a certain value to a certain good (material or symbolic). After all, men mobilise bodies, sexuality, symbols and roles to enact masculinity and avoid a feeling of subjection. By using certain material and symbolic attributes as if these were 'capitals' of manhood, men reflexively trade these capitals (sexual prowess, bodily strength, responsible/provider nature, and so forth) in a sort of market and play of goods, a field, in which more powerful men can be devaluated. These become others in a complex game of otherness played through discursive acts of mockery. This game depends upon the entanglement of different symbolic categories stemming from colonial histories made alive in contemporary Portugal. Past and present, local and global become enmeshed. Many strategies of rebellion against the power held 
by others reveal the desire of achieving a valued masculinity that might be recognised within the hegemonic order.

In this train of thought, two key processes must be considered when analysing postcolonial masculinities: the balance between aspiration and disenchantment, and the dynamics of mimicry and mockery. On the one hand, men aspire to emancipation and a share of hegemony, ${ }^{80}$ which they so often see as unattainable. On the other, disenchantment is blatant in the feelings of exclusion that affect a significant fraction of male migrants, who feel deprived of the material and symbolic 'goods' associated with a powerful masculinity. ${ }^{81}$ Disenchantment is deeply tied with the awareness of being alienated from recognition and redistribution. ${ }^{82}$ Then, in an attempt to escape subordination and disenchantment, mimicry and mockery play a key role. Following Bhabha, as aspiration faces disenchantment, mimicry also becomes more subversive as it slides into mockery, and the old colonized becomes the observer. ${ }^{83}$ Through this process old symbols are resignified and categories reconstructed in ways that generate new forms of enacting postcolonial masculinity.

In postcolonial Portugal, migrant men also find themselves caught up between different 'worlds' of meaning. However, rather than simply adapting to western ways, masculinities and gender relations are evolving into hybrid forms where flexibility (of symbols, practices, citizenship or self-identity) is key. Although flexibility underpins transnationality, ${ }^{84}$ any view that overemphasises utopian conceptions of free individuals crafting their own flexible and globally hybrid identities, obfuscates how all processes of transnationalisation are inextricably linked to global inequity and historical oppression. ${ }^{85}$ In conclusion, masculinities cannot be interpreted without interweaving past and present, global and local as the constituencies of transnationalisation processes, which always were and are a colonial and postcolonial reality. 


\section{Notes}

${ }^{1}$ Michael Hardt and Antonio Negri, Empire, Twenty Years On. New Left Review 120, November-December, 2019, 69.

2 Tim Carrigan, R.W Connell and John Lee, Towards a new sociology of masculinity, Theory and Society, 14(5), 1985, 551-604; and, R.W. Connell, Gender and Power: Society, the Person and Sexual Politics, Cambridge: Polity Press, 1987.

${ }^{3}$ R.W. Connell, Masculinities and Globalisation, Men and Masculinities, 1(1), 1998, 323; and, R.W. Connell and Julian Wood, Globalisation and Business Masculinities, Men and Masculinities, 7 (4), 2005, 347-364.

${ }^{4}$ Marcos Nascimento and Raewyn Connell, Reflecting on twenty years of Masculinities: an interview with Raewyn Connell, Ciência \& Saúde Coletiva, 22(12), 2017, 3977.

${ }^{5}$ The prominence of class and financial capital in Connell's theoretical edifice raised criticism, although some consider that 'A sociology of ruling-class men is long overdue'. See Michael Donaldson, What is hegemonic masculinity? Theory and Society 22(5), $1993,655$.

${ }^{6}$ Connell, Masculinities and Globalisation, 1998, $15 \mathrm{ff}$.

${ }^{7}$ For a critical overview, see Jeff Hearn, From hegemonic masculinity to the hegemony of men, Feminist Theory, 5(1), 2004, 97-120; Christine Beasley, Rethinking Hegemonic Masculinity in a Globalizing World, Men and Masculinities 11:1, 2008, 86-103; and, Richard Howson, Re-Thinking Aspiration and Hegemonic Masculinity in Transnational Context. Masculinities and Social Change, 3:1, 2014, 18-35.

${ }^{8}$ E.g. Jeff Hearn, Men of the World: Genders, Globalisations, Transnational Times, London: Sage, 2015; AUTHOR, 2019. 
${ }^{9}$ R.W. Connell, Masculinities, Cambridge: Polity Press, 1995; and, R.W. Connell and James W. Messerschmidt, Hegemonic masculinity: Rethinking the concept, Gender and Society, 19(6), 2005, 829-859.

${ }^{10}$ Connell, Gender and Power, 1987, 183.

${ }^{11}$ Although Connell distinguishes between subordinated and marginalised masculinities (see Connell, Masculinities, 1995), we use the term subordinate as an umbrella for all enactments of masculinity discriminated on the basis of race, class, sexual orientation or delegitimised gendered enactments. Rather than conflating different forms of marginalisation, and by reframing Gramsci's notion of 'subaltern social groups' we intend to emphasise how all non-hegemonic masculinities share a subordinated status. See Antonio Gramsci, Letters from Prison, London: Quartet, 1979 (1947), or, for an overview, El Habib Louai, Retracing the concept of the subaltern from Gramsci to Spivak: Historical developments and new applications, African Journal of History and Culture 4(1), 2012, 4-8.

12 Frank Cooper, Against Bipolar Black Masculinity: Intersectionality, Assimilation, Identity Performance, and Hierarchy, University of California-Davis Law Review, 2007, 39.

${ }^{13}$ Howson, Re-Thinking Aspiration and Hegemonic Masculinity, 3:1, 2014, 25.

14 See, for instance, Lahoucine Ouzgane and Daniel Coleman, Introduction: Postcolonial Masculinities, Jouvert: A Journal of Postcolonial Studies, Special Issue: Postcolonial Masculinities, 1(2), 1998. Amongst others, see also, Amal Treacher Kabesh, Postcolonial Masculinities: Emotions, Histories and Ethics, Routledge, 2013.

${ }^{15}$ R.W. Connell, Globalization, imperialism and masculinities, in Handbook of Studies on Men and Masculinities, edited by M. Kimmel, J. Hearn and R.W. Connell, Thousand Oaks: Sage, 2005, 71-89. 
$\overline{16}$ See, among others, Mike Donaldson and others, Migrant Men: Critical Studies of Masculinities and the Migration Experience, New York: Routledge, 2009.

${ }^{17}$ See, among others, Andrea Cornwall and Nancy Lindisfarne, Dislocating Masculine Comparative Ethnographies, New York: Routledge, 1994; Robert Morrel, ed., Changing Men in Southern Africa, Pietermaritzburg and London: University of Natal Press and Zed Press, 2001; Dorothy L. Hodgson, Of modernity/modernities, gender and ethnography, in Gendered Modernities: Ethnographic perspectives, edited by D. L. Hodgson, London: Palgrave Macmillan, 2001, 1-25; Lisa A. Lindsay and Stephan F. Miescher, eds., Men and Masculinities in Modern Africa, Portsmouth, NH: Heinemann, 2003; Michael Kimmel, Jeff Hearn and Raewyn Connell, Handbook of Studies on Men and Masculinities, Thousand Oaks: Sage, 2005; Lahoucine Ouzgane and Robert Morrell, eds., African Masculinities: Men in Africa from the Late Nineteenth Century to the Present, New York and Basingstoke: Palgrave Macmillan, 2005; Richard Howson, Deconstructing hegemonic masculinity: Contradiction, hegemony and dislocation, NORMA: Nordic Journal for Masculinity Studies 4, 2009, 7-21.

18 Arjun Appadurai, Modernity at Large: Cultural Dimensions of Globalisation, Minneapolis: University of Minnesota Press, 1996.

${ }^{19}$ Eric Anderson, Inclusive Masculinity: The Changing Nature of Masculinities, London: Routledge, 2009, 42.

20 Michael Kimmel, Masculinity as homophobia: Fear, shame and silence in the construction of gender identity, in Theorizing masculinities, edited by H. Brod and M. Kaufman, Newbury Park, CA: Sage, 1994, 119-141, among others.

${ }^{21}$ A notion mobilized by Göran Therborn, Between Sex and Power: Family in the World, 1900-2000, London: Routledge, 2004. 
${ }^{22}$ Loïc Wacquant, Body \& Soul: Notebooks of an Apprentice Boxer, New York: Oxford University Press, 2004.

${ }^{23}$ Tony Coles, Negotiating the Field of Masculinity. The Production and Reproduction of Multiple Dominant Masculinities, Men and Masculinities 12 (1), 2009, 37.

${ }^{24}$ E.g. AUTHOR, 2009.

${ }^{25}$ AUTHOR, 2019.

${ }^{26}$ Anderson, Inclusive Masculinity, 2009.

${ }^{27}$ Coles, Negotiating the Field of Masculinity, 2009, 30-44.

${ }^{28}$ Gramsci, Letters from Prison, 1979 (1947). See also Donaldson, What is hegemonic masculinity? 1993, and Hearn, From hegemonic masculinity to the hegemony of men, 2004.

${ }^{29}$ Pierre Bourdieu, Esquisse d'Une Théorie de la Pratique, Précédé de Trois Études d'Ethnologie Kabyle, Geneva: Droz, 1972, and La Distinction. Critique Sociale du Jugement, Paris, Minuit, 1979.

${ }^{30}$ Pierre Bourdieu, Quelques propriétés des champs. Questions de sociologie, Paris: Minuit, 1984, 113-120.

${ }^{31}$ For a critical view of Bourdieu and transnational analysis, see Christian SchmidtWellenburg and Stefan Bernhard, Charting Transnational Fields. Methodology for a Political Sociology of Knowledge, London: Routledge, 2020.

${ }^{32}$ Karl Marx, The Economic and Philosophic Manuscripts of 1844 (by Karl Marx) and the Communist Manifesto (by Karl Marx and Friedrich Engels), New York: Prometheus Books, 1988 (1844).

${ }^{33}$ Jean Baudrillard, The system of objects. London: Verso, 1996 (1968).

${ }^{34}$ Michael Hardt and Antonio Negri, Empire. Cambridge, MA: Harvard University Press, 2001. 
35 In 1846, Marx had already wrote, in a letter to Pavel Vasilyevich Annenkov: 'Without slavery there would be no cotton, without cotton there would be no modern industry. It is slavery that has given value to the colonies, it is the colonies that have created world trade, and world trade is the necessary condition for large-scale machine industry. Slavery is therefore an economic category of paramount importance.' Karl Marx, The poverty of philosophy: answer to the 'Philosophy of Poverty' by M. Proudhon, Moscow: Progress Publishers, 1975 (1846).

${ }^{36}$ R.W Connell, Lahoucine Ouzgane and Daniel Coleman, Cashing out the Patriarchal Dividends: An Interview with R. W. Connell. Jouvert: A Journal of Postcolonial Studies, Special Issue: Postcolonial Masculinities, 1(2), 1998.

${ }^{37}$ E.g. Therborn, Between Sex and Power, 2004.

${ }^{38}$ David Casassas and Peter Wagner, Modernity and capitalism: Conceptual retrieval and comparative-historical analyses, European Journal of Social Theory, 19(2), 2016, 162.

39 Bernard Yack, The Fetishism of Modernities: Epochal Self-Consciousness in Contemporary Social and Political Thought, Notre Dame: University of Notre Dame Press, 1997.

${ }^{40}$ Hardt and Negri, Empire, Twenty Years On, 2019, 67-92.

${ }^{41}$ Shmuel N. Eisenstadt, Multiple modernities, Daedalus, 129(1), 2000, 1-29.

${ }^{42}$ Göran Therborn, Entangled Modernities. European Journal of Social Theory 6 (3), 2003, 293-305.

${ }^{43}$ E.g. Stanley J. Tambiah, Transitional movements, diaspora, and multiple modernities, Daedalus 129 (1), 2000, 163-194.

${ }^{44}$ Ulrich Beck, The cosmopolitan perspective: sociology of the second age of modernity, British Journal of Sociology, 51 (1), 2000, 79-105.

${ }^{45}$ Homi Bhabha, Location of Culture, London: Routledge, 1994. 
46 Ibrahim Kaya, Modernity, openness, interpretation: a perspective on multiple modernities. Social Science Information 43 (1), 2004, 35-57.

${ }^{47}$ Frantz Fanon, Black Skin White Mask, New York: Grove, 1967.

${ }^{48}$ For instance, Bhabha (Location of Culture) or Appadurai (Modernity at Large).

${ }^{49}$ Valentim Alexandre, Velho Brasil Novas Áfricas: Portugal e o Império (1808-1975), Porto: Afrontamento, 2000.

${ }^{50}$ Catarina Reis Oliveira and Natália Gomes, Indicadores de integração de imigrantes: relatório estatístico anual, Lisbon: Alto Comissariado para as Migrações, 2018.

${ }^{51}$ Technically from 1933 to 1974 , since the period between 1926 and 1933 is designated as Ditadura Nacional (National Dictatorship).

${ }^{52}$ It should, however, be clearly distinguished from the independence processes of Spanish dominated America, as Brazilian independence was proclaimed by the heir to the Portuguese throne (the Portuguese Royal Court and House had relocated to Brazil in 1808, following French Napoleonic invasions of European Portuguese territory), leading to the establishment of the Empire of Brazil under a monarch of the same ruling royal house as Portugal.

${ }^{53}$ Gilberto Freyre, Casa Grande \& Senzala, São Paulo: Global, 2003 (1933).

${ }^{54}$ E.g. Peter Burke and Maria Lúcia Pallares-Burke, Gilberto Freyre: Social theory in the tropics, Oxfordshire: Peter Lang, 2008.

${ }^{55}$ As in Spain, this persecution was not only religious but in fact essentially 'racial', producing a wide array of legal instruments aimed at the genealogical surveillance of any and all 'blemish of impure nation' and the maintenance of 'purity of blood'.

56 Jorge Vala, Rodrigo Brito and Diniz Lopes, Expressões dos racismos em Portugal, Lisbon: Imprensa de Ciências Sociais, 2015. 
${ }^{57}$ Thais França and Beatriz Padilla, Imigração brasileira para Portugal: entre o surgimento e a construção midiática de uma nova vaga, Cadernos de Estudos Sociais, 33(2), 2018, $1-30$.

${ }^{58}$ Bourdieu, Esquisse, 1972, and La Distinction, 1979.

59 Adam Isaiah Green, The Social Organisation of Desire: The Sexual Fields Approach, Sociological Theory, 26, 2008, 25-56.

${ }^{60}$ Wacquant, Body \& Soul, 2004.

${ }^{61}$ Coles, Negotiating the Field of Masculinity, 2009, 30-44.

${ }^{62}$ See Margaret L. Hunter, Buying Racial Capital: Skin-Bleaching and Cosmetic Surgery in a Globalized World, The Journal of Pan African Studies, 4 (4), June 2011, 145. As Hunter argues: 'Racial capital is a resource drawn from the body that can be related to skin tone, facial features, body shape, etc. She explains: 'I use the term "racial capital" to describe the role that white/Anglo bodies play in the status hierarchy.'

${ }^{63}$ Sara Ahmed, Strange Encounters: Embodied Others in Post-Coloniality, London: Routledge, 2000.

${ }^{64}$ Bhabha, Location of Culture, 1994, 87.

${ }^{65}$ Rafael Guerreiro Osório, O Sistema Classificatório de 'Cor ou Raça' do IBGE, Brasília: IPEA, 2003.

${ }^{66}$ Peter Fry, The politics of 'racial' classification in Brazil. Journal de la société des américanistes, 95-2, 2009, 261-282.

${ }^{67}$ Francisco Bethencourt, Racisms: from the crusades to the twentieth century, Princeton: Princeton University Press, 2013.

${ }^{68}$ Patrícia de Santana Pinho, Reinvenções da África na Bahia, São Paulo: Annablume, 2004. 
${ }^{69}$ Cláudio Alves Furtado, Raça, classe e etnia nos estudos sobre e em Cabo Verde: as marcas do silêncio, Afro-Ásia, 45, 2012, 143-171.

${ }^{70}$ Freyre, Casa Grande \& Senzala, 2003 (1933).

71 Stuart Hall, Cultural Identity and Diaspora. In Identity: Community, Culture, Differences, edited by J. Rutherford. London: Lawrence and Wishart, 1990, 225.

72 Anne McClintock, Imperial Leather: Race, gender and sexuality in the colonial context, New York: Routledge, 1995, 22.

${ }^{73}$ Jon Binnie, The globalisation of sexuality, London: Sage, 2004, 17.

${ }^{74}$ The work of Mrinalini Sinha helped us to understand British and Indian social history within a comparable framework. As Sinha demonstrated, the figure of the "manly Englishman' was deemed hierarchically superior to the images of the 'effeminate Bengali'. In the postcolonial social formation, subaltern migrant men turn old colonial strategies against the former colonizers. See Mrinalini Sinha, Colonial masculinity. The 'Manly Englishman' and the 'Effeminate Bengali' in the Late Nineteenth Century, Manchester: Machester University Press.

${ }^{75}$ Similar findings are applicable to Turkish immigrant men in Germany. Ralf Bohnsack, Peter Loos and Aglaja Przyborski, 'Male honor': Towards an understanding of the construction of gender relations among youths of Turkish origin, in Gender in Interaction: Perspectives on Femininity and Masculinity in Ethnography and Discourse, edited by B. Baron and H. Kotthoff, Amsterdam \& Philadelphia: John Benjamins Publishing Company, 2001, 175-207.

${ }^{76}$ Baudrillard, The system of objects, 1996 (1968).

${ }^{77}$ Assimilado is the Portuguese word officially applied to those Africans and mestiços considered by the colonial authorities to have met certain formal standards indicating that they had successfully absorbed (assimilated) the Portuguese language and culture. In 
principle, individuals legally assigned the status of assimilado took on the privileges and obligations of Portuguese citizens and escaped the burdens imposed on most Africans (the indígenas). The status of assimilado and its legal implications were formally abolished in 1961.

78 Allen Isaacman, Coercion, Paternalism and the Labour Process: The Mozambican Cotton Regime 1938-1961, Journal of Southern African Studies 18(3), 1992, 487-526, and Signe Arnfred, Conceptions of gender in colonial and post-colonial discourses: The case of Mozambique, Uganda: Kampala, 2002.

${ }^{79}$ Hardt and Negri, Empire, Twenty Years On, 2019, 73.

${ }^{80}$ E.g. Howson, Deconstructing hegemonic masculinity, 2009, 7-21.

81 On how uneasy feelings of desire and shame are embedded in postcolonial constructions of masculinity amongst Egyptian men, see the work of Kabesh, Postcolonial Masculinities, 2013.

82 Axel Honneth and Nancy Fraser Redistribution or Recognition?: A PoliticalPhilosophical Exchange, London: Verso, 2003.

${ }^{83}$ Bhabha, Location of Culture, 1994, 127.

${ }^{84}$ Aihwa Ong, Flexible Citizenship: the Cultural Logics of Transnationality, Durham: Duke University Press, 1999, 6.

85 While transnationality/transnationalism offers the lens to describe processes of dislocation (trasnationalisations), more theorizing is still needed in the field. For an overview, see, Sara de Jong and Petra Dannecker, Connecting and confronting transnationalism: bridging concepts and moving critique, Identities, 25:5, 2018, 493-506. 


\section{Funding}

This paper drew on data initially collected with funding from the Portuguese Foundation for Science and Technology. The final stage of the research leading to these results received funding from the European Research Council under the European Union's Seventh Framework Programme (FP/2007-2013)/ERC Grant Agreement n. ${ }^{\circ} 615594$.

\section{Notes on contributors}

Sofia Aboim is a permanent research fellow at the Institute of Social Sciences of the University of Lisbon. Her research interests include gender, feminisms, masculinity studies as well as social theory, justice, inequality and post-colonial studies. She is currently working on book projects about gender futures, power and justice while developing research on the same topics. She coordinates the project TRANSRIGHTS Gender citizenship and sexual rights in Europe (Consolidator Grant) financed by the European Research Council (ERC).

Pedro Vasconcelos is a tenured Auxiliary Professor at the Department of Sociology of the Iscte University Institute of Lisbon, where he teaches and does research since the midnineties. His present research interests deal with subjects of social inequality, generations and the life course, gender theory, gender relations and categorizations, masculinities and femininities, transgender issues and institutional orders. He is a senior researcher in the project TRANSRIGHTS - Gender citizenship and sexual rights in Europe, financed by the European Research Council (ERC). 